\title{
Nicotinamide, Folic Acid and Derivatives as Potent Inhibitors of Inflammatory Factors against Novel Corona Virus Infection
}

\section{Hemanth Kumar Manikyam ${ }^{1 *}$ and Sunil K Joshi'}

${ }^{1}$ Faculty of Science, North East Frontier Technical University, Arunachal Pradesh, India ${ }^{2}$ Assistant Professor, Cellular Immunology/Hemoglobinopathies, Division of Hematology/Oncology and Bone Marrow Transplantation, Department of Paediatrics, University of Miami Miller School of Medicine, Miami, FL, USA

*Corresponding Author: Hemanth Kumar Manikyam, Faculty of Science, North East Frontier Technical University, Arunachal Pradesh, India.
Received: March 20, 2020

Published: April 16, 2020

(C) All rights are reserved by Hemanth Kumar Manikyam and Sunil K Joshi
A novel coronavirus designated as SARS-CoV-2 in February 2020 by World Health organization (WHO) was identified as main cause of SARS like pneumonia cases in Wuhan city in Hubei Province of China at the end of 2019. This been recently declared as Global Pandemic by WHO. There is a global emergency to identify potential drugs to treat the SARS-CoV-2. Currently, there is no specific treatment against the new virus. There is an emergency to identifying potential antiviral agents to combat the disease is urgently needed. An effective and quick approach is to test existing antiviral drugs against COVID-19. Patients affected with Novel coronavirus had shown severe respiratory inflammatory burst which includes sever cytokine and lymphocyte over responses. Particularly interleukins swarm like IL8, IL2, IL6 and other inflammatory triggering factors. Nicotinamide also known as Vitamin B3 a derivative of amide had a powerful anti-inflammatory properties which includes inhibition of free radicals scavenging, Nitric oxide synthase activity. Niacinamide also had shown inhibitory property against Poly (ADP ribose) polymerase (PARP), a Nuclear DNA binding enzyme to repair and response during genotoxic stress. PARP activation leads to NAD+ depletion leading slowing down of cell metabolism and leading cell death. Genome wide analysis and open reading frames of Novel Coronavirus had shown many gene codes for Poly (ADP ribose) polymerase (PARP) which indicates Novel coronavirus uses host enzymes using its genetic code to infect and replicate. Nicotinamide also suppresses the MHC class II expression and ICAM-1 expression leading to reduction in inflammatory factors production. Proinflammatory cytokines like IL-1 $\beta$, IL-8, IL-6, IL-2 and TNF $\alpha$ plays key role in respiratory outburst during Coronavirus infection. Use of Nicotinamide in patients suffering from Coronavirus infection may prevent Respiratory outburst by inhibiting Cytokine production. We propose use of FOLIC ACID , Riboflavin and zinc supplements as a palliative treatment for patients infected with Coronavirus in order to control inflam- matory factors production and viral replication. We also propose use of anti-inflammatory drugs against Proinflammatory cytokines like IL-1 $\beta$, IL-8, IL-6, IL-2 and TNF $\alpha$ [1-4].

\section{Bibliography}

1. Philippe A Grange., et al. "Nicotinamide inhibits Propionibacterium acnes-induced IL-8 production in keratinocytes through the NF-kB and MAPK pathways". Journal of Dermatological Science 56.2 (2009): 106-112.

2. Raphael G., et al. "Neutrophil recruitment is inhibited by Nicotinamide in experimental pleurisy in mice". European Journal of Pharmacology 685.1-3 (2012): 198-204.

3. G Monfrecola., et al. "Nicotinamide down regulates gene expression of interleukin-6, interleukin-10, monocyte chemoattractant protein-1, and tumour necrosis factor- $\alpha$ gene expression in HaCaT keratinocytes after ultraviolet B irradiation". Clinical and Experimental Dermatology 38.2 (2013): 185-188.

4. Rafał Biedron., et al. "1-Methylnicotinamide and Nicotinamide: two related anti-inflammatory agents that differentially affect the functions of activated macrophages". Archivum Immunologiae et Therapiae Experimentalis 56.2 (2008): 127-134.

\section{Assets from publication with us}

- Prompt Acknowledgement after receiving the article

- Thorough Double blinded peer review

- Rapid Publication

- Issue of Publication Certificate

- High visibility of your Published work

Website: https://www.actascientific.com/

Submit Article: https://www.actascientific.com/submission.php Email us: editor@actascientific.com

Contact us: +919182824667 